doi:10.1016/j.gca.2005.01.027

\title{
Surface chemistry of disordered mackinawite (FeS)
}

\author{
Mariëtte Wolthers, ${ }^{1} *$ Laurent Charlet, ${ }^{2}$ Peter R. van Der Linde, ${ }^{3}$ David Rickard, ${ }^{4}$ and Cornelis H. van Der Weijden ${ }^{1}$ \\ ${ }^{1}$ Department of Earth Sciences - Geochemistry, Faculty of Geosciences, Utrecht University, Utrecht, The Netherlands \\ ${ }^{2}$ Laboratoire de Géophysique Interne et Tectonophysique, Université Grenoble I, Grenoble, France \\ ${ }^{3}$ University of Professional Education Leiden, Leiden, The Netherlands \\ ${ }^{4}$ School of Earth, Ocean and Planetary Sciences, Cardiff University, Cardiff, Wales UK
}

(Received February 23, 2004; accepted in revised form January 28, 2005)

\begin{abstract}
Disordered mackinawite, FeS, is the first formed iron sulfide in ambient sulfidic environments and has a highly reactive surface. In this study, the solubility and surface chemistry of FeS is described. Its solubility in the neutral $\mathrm{pH}$ range can be described by $K_{\mathrm{s} p}^{\mathrm{app}}=\left\{\mathrm{Fe}^{2+}\right\} \cdot\left\{\mathrm{H}_{2} \mathrm{~S}(\mathrm{aq})\right\} \cdot\left\{\mathrm{H}^{+}\right\}^{-2}$ $=10^{+4.87 \pm 0.27}$. Acid-base titrations show that the point of zero charge (PZC) of disordered mackinawite lies at $\mathrm{pH} \sim 7.5$. The hydrated disordered mackinawite surface can be best described by strongly acidic monocoordinated and weakly acidic tricoordinated sulfurs. The mono-coordinated sulfur site determines the acid-base properties at $\mathrm{pH}<\mathrm{PZC}$ and has a concentration of $1.2 \times 10^{-3} \mathrm{~mol} / \mathrm{g} \mathrm{FeS}$. At higher $\mathrm{pH}$, the tricoordinated sulfur, which has a concentration of $1.2 \times 10^{-3} \mathrm{~mol} / \mathrm{g} \mathrm{FeS}$, determines surface charge changes. Total site density is 4 sites $\mathrm{nm}^{-2}$. The acid-base titration data are used to develop a surface complexation model for the surface chemistry of FeS. Copyright (C) 2005 Elsevier Ltd
\end{abstract}

\section{INTRODUCTION}

Disordered mackinawite is a highly reactive phase with a high adsorptive capacity for divalent metals (e.g., Kornicker, 1988; Arakaki and Morse, 1993; Morse and Arakaki, 1993; Wharton et al., 2000). Anoxic marine sediment pore waters are saturated with respect to disordered mackinawite (Berner, 1967; Spadini et al., 2003). It is the first iron sulfide to form in most ambient environments, and with time, it reacts to form more stable iron sulfide phases such as ordered mackinawite, greigite, and ultimately pyrite or pyrrhotite. In this paper, disordered mackinawite is defined as the first precipitated iron(II) monosulfide phase formed through the reaction between aqueous $\mathrm{Fe}(\mathrm{II})$ and sulfide under ambient conditions. Lennie and Vaughan (1996) showed that this phase, which is sometimes referred to as "amorphous FeS," displays long-range mackinawite ordering. Here, this phase is referred to as FeS.

The bulk structure of FeS was studied by Wolthers et al. (2003) by X-ray powder diffraction measurements (XRPD). They showed that synthetic FeS displays a disordered tetragonal mackinawite structure and that it is nanocrystalline, with an average primary particle size equivalent to a crystallite size of $4 \mathrm{~nm}$, and a corresponding specific surface area of $350 \mathrm{~m}^{2} \mathrm{~g}^{-1}$ (Table 1). FeS was described in terms of a mixture of two end-member phases with different long-range ordering, with the relative proportions of the end members varying with age, and probably with formation conditions. Lattice expansions of up to 54 vol\% relative to crystalline mackinawite were explained by intercalation of water molecules between the tetrahedral sheets and by lattice relaxation due to small crystallite size.

Fundamental surface chemical properties have not been reported for disordered mackinawite. In fact, experimental characterization studies of sulfide surfaces are rare in general,

* Author to whom correspondence should be addressed (wolthers@geo.uu.nl). despite the accepted importance of the reactivity of sulfides in the geochemical cycles of many trace elements (e.g., Kornicker, 1988; Arakaki and Morse, 1993; Morse and Arakaki, 1993; Morse and Luther, 1999; Wharton et al., 2000). With the notable exception of the structural and magnetic study by Watson et al. (2000) on an iron sulphide mixture of disordered mackinawite and greigite that was formed by sulfate-reducing bacteria, all recent studies aiming to describe the surface properties of metal sulfides pertained to the more crystalline solid. Potentiometrically derived point of zero charge $\left(\mathrm{pH}_{\mathrm{PZC}}\right)$ data are available for crystalline iron sulfides (Widler and Seward, 2002), zinc sulfide (Rönngren et al., 1991), lead sulfide (Sun et al., 1991), arsenic and antimony sulfide (Renders and Seward, 1989), and for cadmium sulfide (Park and Huang, 1987). Dekkers and Schoonen (1994) and Bebié et al. (1998) employed electrophoresis to study the charge development of sulfides as a function of $\mathrm{pH}$. They found that the isoelectric points for several crystalline metal sulfides lie below $\mathrm{pH} \sim 3.3$ and showed that the sulfide surface was largely dominated by sulfide groups.

The objective of this study is to describe the experimentally determined surface properties of synthetic FeS produced by reacting aqueous $\mathrm{Fe}$ (II) with aqueous sulfide. The solubility of $\mathrm{FeS}$ in the neutral $\mathrm{pH}$ range is addressed and the acid-base properties of the FeS surface are characterized using potentiometric titrations. Subsequently, the potentiometric titration data are used to propose a surface complexation model that is supported by crystal structural considerations.

\section{MATERIALS AND METHODS}

\subsection{Materials}

All chemicals were of analytical grade and used without further purification; solutions were prepared from Milli-Q water and purged for at least $30 \mathrm{~min}$ with $\mathrm{O}_{2}$-free $\mathrm{N}_{2}$ before use. Solutions of $\mathrm{S}(-\mathrm{II})$ and $\mathrm{Fe}(\mathrm{II})$ were prepared before every experiment by dissolving $\mathrm{Na}_{2} \mathrm{~S} \cdot 9 \mathrm{H}_{2} \mathrm{O}$ by Fisher Chemicals (Emergo), the Netherlands and Mohr's salt $\left(\mathrm{Fe}\left(\mathrm{NH}_{4}\right)_{2}\left(\mathrm{SO}_{4}\right)_{2} \cdot 4 \mathrm{H}_{2} \mathrm{O}\right.$; Merck (VWR), the Nether- 
Table 1. Properties of disordered mackinawite.

\begin{tabular}{lccc}
\hline $\begin{array}{c}\text { SSA } \\
\left(\mathrm{m}^{2} \mathrm{~g}^{-1}\right)\end{array}$ & $\begin{array}{c}\text { Average diameter } \\
(\mathrm{nm})\end{array}$ & $\begin{array}{c}\text { Site density } \\
\left(\operatorname{sites~nm}^{-2}\right)\end{array}$ & $\begin{array}{c}{[\equiv \mathrm{FeS}]} \\
\left(\mathrm{mmol} \mathrm{g}^{-1} \mathrm{FeS}\right)\end{array}$ \\
\hline
\end{tabular}

$350 \quad 4.2 \pm 0.2$

4.0

1.2

1.2

SSA = specific surface area (Wolthers et al., 2003); average diameter $=$ the average primary particle size (Wolthers et al., 2003), site density $=$ the density of sites at the surface; $[\equiv \mathrm{FeS}]=$ the concentration of mono-coordinated sulfur sites at the surface; $\left[\equiv \mathrm{Fe}{ }_{3} \mathrm{~S}\right]=\mathrm{the}_{\mathrm{B}}$ concentration of tri-coordinated sulfur sites at the surface.

lands), which is relatively resistant to oxidation, in background electrolyte of varying $\mathrm{KNO}_{3}$ by Fisher Chemicals (Emergo), the Netherlands concentration. Because the salts are hydrates, the Fe and $\mathrm{S}$ concentrations were checked regularly by Inductively Coupled PlasmaOptical Emission Spectroscopy (ICP-OES) analysis, where the $\mathrm{Na}$ concentration in the sulfide solution was assumed representative of the sulfide concentration.

Experiments were run under $\mathrm{O}_{2}$-free conditions by directly flushing the reaction vessel with $\mathrm{N}_{2}$, purified by bubbling through a succession of two $15 \mathrm{wt} \%$ pyrogallol in $50 \mathrm{wt} \% \mathrm{KOH}$ solutions to remove $\mathrm{O}_{2}$, a Chrompack oxygen and sulfide scrubber for additional cleaning, and Milli-Q water to saturate the $\mathrm{N}_{2}$ with water vapor. The $\mathrm{O}_{2}$ concentration in the reaction vessels was below $1 \times 10^{-6} \mathrm{M}$, which is the detection limit of the Orion oxygen probe (850).

Fresh FeS suspensions for potentiometric titrations was synthesized in situ by adding a $1 \times 10^{-3} \mathrm{M} \mathrm{S}\left(-\right.$ II) solution to a $1 \times 10^{-3} \mathrm{M} \mathrm{Fe}$ (II) solution in the reaction vessel while constantly flushing with $\mathrm{N}_{2}$. FeS formed rapidly and was left to age in the reaction vessel for at least half an $\mathrm{h}$ before the initial $\mathrm{pH}$ was set, and one $\mathrm{h}$ before experimentation started. The suspensions were stirred magnetically with a Teflon-coated stirring bar.

\subsection{Solubility}

Since the solubility will depend on the method of synthesis (e.g., Davison, 1991), and dissolution of the solid will influence the proton balance determined in the potentiometric titration, the solubility of the synthetic FeS used in this study needs to be determined. Note that all species are aqueous unless otherwise indicated, and that equilibrium is assumed between all solution species and with the solid.

The solubility of FeS can be expressed by reaction 1:

$$
\mathrm{FeS}(\mathrm{s})+2 \mathrm{H}^{+} \leftrightarrow \mathrm{Fe}^{2+}+\mathrm{H}_{2} \mathrm{~S}(\mathrm{aq}) \quad K_{\mathrm{s}}^{\text {app }}
$$

$K_{\mathrm{s}}^{\text {app }}$ is the apparent solubility constant at zero ionic strength that is derived from the experimental $\mathrm{pH}$ and total dissolved $\mathrm{Fe}$ data and compared to the solubility $K_{\mathrm{s}}^{*}=10^{+3.98 \pm 0.12}$ from Davison et al. (1999), recalculated from their $K_{\mathrm{s}}^{*}=\left\{\mathrm{Fe}^{2+}\right\} \cdot\left\{\mathrm{HS}^{-}\right\} \cdot\left\{\mathrm{H}^{+}\right\}^{-1}$ $=10^{-3.00 \pm 0.12}$ by using $K_{1}=\left\{\mathrm{H}_{2} \mathrm{~S}(\mathrm{aq})\right\} \cdot\left\{\mathrm{HS}^{-}(\mathrm{aq})\right\}^{-1} \cdot\left\{\mathrm{H}^{+}(\mathrm{aq})\right\}^{-1}$ $=10^{+6.98}$ (Suleimonov and Seward, 1997). A 1:1 iron-to-sulfide stoichiometry is assumed, based on Energy Dispersive X-ray spectra collected on freeze-dried FeS particles (Wolthers et al., 2003). Furthermore, dissolution is assumed to be congruent. The aqueous sulfide chemistry is represented by the following reactions:

$$
\begin{gathered}
\mathrm{H}_{2} \mathrm{~S}(\mathrm{aq}) \leftrightarrow \mathrm{HS}^{-}+\mathrm{H}^{+} \quad K_{1} \\
\mathrm{H}_{2} \mathrm{~S}(\mathrm{~g}) \leftrightarrow \mathrm{H}_{2} \mathrm{~S}(\mathrm{aq}) \quad K_{\mathrm{H}}
\end{gathered}
$$

where $K_{1}=10^{-6.98}$ (Suleimonov and Seward, 1997) and $K_{\mathrm{H}}$ $=\left\{\mathrm{H}_{2} \mathrm{~S}(\mathrm{aq})\right\} P_{\mathrm{H} 2 \mathrm{~S}}^{-1}=10^{+0.99}$ (Morel and Hering, 1993) at zero ionic strength. A closed-system equilibrium with respect to hydrogen sulfide gas is assumed. Calculation shows that at a conservatively estimated purging rate of $100 \mathrm{~mL}$ per min, within the time frame of our experiments $(<42 \mathrm{~h}), 0.1 \%$ of the sulfide present would degas if the system would have been at $\mathrm{pH} 6$ continuously and at $\mathrm{pH} 8$, this decreases to $0.0003 \%$. In reality, the titration cell was only briefly at $\mathrm{pH} 6(<1 \mathrm{~h})$, and the average time of titration experiments was 8 h, 40 min. Accordingly, reaction 3 will be ignored in further calculations.

Aqueous iron-sulfide complexation plays an important role in this pH range (Rickard, 1989; Davison, 1991; Luther, 1991; Luther and
Ferdelman, 1993; Zhang and Millero, 1994; Rickard, 1995; Luther et al., 1996; Davison et al., 1999). The two most simple complexation reactions reported are

$$
\begin{gathered}
\mathrm{FeS}(\mathrm{s})+\mathrm{H}^{+} \leftrightarrow \mathrm{FeSH}^{+} \\
\mathrm{FeS}(\mathrm{s})+\mathrm{H}_{2} \mathrm{~S}(\mathrm{aq}) \leftrightarrow \mathrm{Fe}(\mathrm{SH})_{2}^{0}
\end{gathered}
$$

where $\beta_{1}=10^{+2.05 \pm 0.5}$ (Luther et al., 1996), $\beta_{2}=10^{-3.43 \pm 0.1}$ (Davison et al., 1999). The way reactions 4,5 , and 1 are written simplifies further derivations; no assumptions about the actual reactive species or reaction mechanisms are made. Davison et al. (1999) determined a much lower value for $\beta_{1}$, that is, $\beta_{1}=10^{+0.05 \pm 0.1}$. There is still considerable disagreement on aqueous iron-sulfide complexation reactions and their thermodynamic constants, the latter should therefore be treated with caution (Davison et al., 1999). It may be that the ironsulfide complexation is sensitive to FeS characteristics, which in turn are sensitive to the preparation method (Davison, 1991). Since in this study FeS was prepared using the same method as Luther et al. (1996), their higher $\beta_{1}$ value is adopted.

From 1 to 5 , the definitions for the activities of the sulfide species and aqueous iron(II)-sulfide complexes can be derived:

$$
\begin{gathered}
\left\{\mathrm{H}_{2} \mathrm{Saq}\right)=\frac{K_{\mathrm{s}}^{\mathrm{app}}\left\{\mathrm{H}^{+}\right\}^{2}}{\left\{\mathrm{Fe}^{2+}\right\}} \\
\left\{\mathrm{HS}^{-}\right\}=\frac{K_{1}\left\{\mathrm{H}_{2} \mathrm{~S}(\mathrm{aq})\right\}}{\left\{\mathrm{H}^{+}\right\}}=\frac{K_{1} K_{\mathrm{s}}^{\mathrm{app}}\left\{\mathrm{H}^{+}\right\}}{\left\{\mathrm{Fe}^{2+}\right\}} \\
\left\{\mathrm{FeSH}^{+}\right\}=\beta_{1}\left\{\mathrm{H}^{+}\right\} \\
\left\{\mathrm{Fe}(\mathrm{SH})_{2}^{0}\right\}=\beta_{2}\left\{\mathrm{H}_{2} \mathrm{~S}(\mathrm{aq})\right\}=\frac{\beta_{2} K_{\mathrm{s}}^{\mathrm{app}}\left\{\mathrm{H}^{+}\right\}^{2}}{\left\{\mathrm{Fe}^{2+}\right\}}
\end{gathered}
$$

Furthermore, the expressions for total iron (Eqn. 10) and total sulfide (Eqn. 11) in the system are known, and it is assumed that the two are equal as a first approximation (Eqn. 12):

$$
\begin{gathered}
\mathrm{Fe}_{\mathrm{T}}=\left[\mathrm{Fe}^{2+}\right]+\left[\mathrm{FeSH}^{+}\right]+\left[\mathrm{Fe}(\mathrm{SH})_{2}^{0}\right]+[\mathrm{FeS}(\mathrm{s})] \\
\mathrm{S}_{\mathrm{T}}=\left[\mathrm{HS}^{-}\right]+\left[\mathrm{H}_{2} \mathrm{~S}(\mathrm{aq})\right]+\left[\mathrm{FeSH}^{+}\right]+2\left[\mathrm{Fe}(\mathrm{SH})_{2}^{0}\right]+[\mathrm{FeS}(\mathrm{s})] \\
{\left[\mathrm{Fe}^{2+}\right]=\left[\mathrm{HS}^{-}\right]+\left[\mathrm{H}_{2} \mathrm{~S}(\mathrm{aq})\right]+\left[\mathrm{Fe}(\mathrm{SH})_{2}^{0}\right]}
\end{gathered}
$$

Combining Eqns. 6 to 12, an expression for the Fe(II) activity is obtained as follows

$$
\begin{aligned}
& \frac{\left\{\mathrm{Fe}^{2+}\right\}}{\gamma_{\mathrm{Fe}}}=\frac{\left\{\mathrm{H}_{2} \mathrm{~S}(\mathrm{aq})\right\}}{\gamma_{\mathrm{H} 2 \mathrm{~S}}}+\frac{\left\{\mathrm{HS}^{-}\right\}}{\gamma_{\mathrm{HS}}}+\frac{\left\{\mathrm{Fe}(\mathrm{SH})_{2}^{0}\right\}}{\gamma_{\mathrm{Fe}(\mathrm{SH})^{2}}}
\end{aligned}
$$

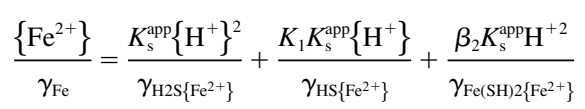

$$
\begin{aligned}
& \left\{\mathrm{Fe}^{2+}\right\}=\sqrt{{ }^{\gamma} \mathrm{Fe} K_{\mathrm{s}}^{\mathrm{app}}\left(\frac{\left\{\mathrm{H}^{+}\right\}^{2}}{{ }^{\gamma} \mathrm{H} 2 \mathrm{~S}}+\frac{K_{1}\left\{\mathrm{H}^{+}\right\}}{{ }^{\gamma} \mathrm{HS}}+\frac{\beta_{2}\left\{\mathrm{H}^{+}\right\}^{2}}{{ }^{\gamma} \mathrm{Fe}(\mathrm{SH}) 2}\right)}
\end{aligned}
$$

To compare the experimental solubility to the literature solubility, it is assumed that the total dissolved iron, $\left[\mathrm{Fe}(\mathrm{aq})_{\mathrm{T}}\right]$, can be equated by 


$$
\left[\mathrm{Fe}(\mathrm{aq})_{\mathrm{T}}\right]=\left[\mathrm{Fe}^{2+}\right]+\left[\mathrm{FeSH}^{+}\right]+\left[\mathrm{Fe}(\mathrm{SH})_{2}^{0}\right]
$$

Substituting Eqns. 8, 9, and 13 into 14, and taking the literature values for the equilibrium constants, Eqn. 14 can be solved for any $\mathrm{pH}$ value. Extrapolation to zero theoretical ionic strength (cf. Davison, 1991) facilitates comparison of the solubility calculated here to the literature solubility; the corrections of the experimental titration data are done with the appropriate activity coefficients. The $K_{\mathrm{s}}^{\text {app }}$ was determined by the best fit method, calculated by multiple least-squares estimation and multiple linear correlation; the error in the solubility constant was taken as twice the standard error of estimate.

\subsection{Surface Characterizations}

The aim of the potentiometric titration was to determine the balance of adsorbed and desorbed protons on the surface of the disordered mackinawite as a function of $\mathrm{pH}$, within the $\mathrm{pH}$ range of 6 to 8 . The $\mathrm{FeS}$ titrations were conducted on in situ precipitated FeS, thus in a background electrolyte solution containing sodium, sulfate, and ammonium as well as the $0.005 \mathrm{M}, 0.05 \mathrm{M}$, or $0.1 \mathrm{M} \mathrm{KNO}_{3}$ ionic medium, giving total ionic strengths of $0.0078 \mathrm{M}, 0.053 \mathrm{M}$, or $0.103 \mathrm{M}$. The titrations were performed from $\mathrm{pH} 8$ to 6 to prevent back precipitation reactions to occur as $\mathrm{pH}$ increases (the $\mathrm{FeS}$ solubility decreases with increasing $\mathrm{pH}$ ). This would have interfered with the surface acid-base reactions. Afterwards, reversibility of the titrations was tested by increasing the $\mathrm{pH}$ back to 8 . The freshly precipitated $0.044 \mathrm{~g} \mathrm{~L}^{-1} \mathrm{FeS}$ suspension was prepared as described above and kept at $23.2 \pm 0.4^{\circ} \mathrm{C}$. In the course of the titrations, $1 \mathrm{~mL}$ samples were taken from the suspension and filtered through $0.2 \mu \mathrm{m}$ Acrodisc filter discs. The total dissolved iron in the filtrates was measured spectrophotometrically by the ferrozine method (Viollier et al., 2000) using a Unicam UV1 spectrophotometer to check for mineral dissolution during titrations. FeS was shown to be nanometer-sized (Wolthers et al., 2003), and it is likely that the efficiency of the filtration process was affected by the small particle size.

Two blank titrations were performed on supernatants that had been collected after filtrating FeS suspensions at $\mathrm{pH} 8$ or 6 through a $0.2 \mu \mathrm{m}$ Millipore filter. In this way, not only contributions to the surface charge by matrix species are accounted for, but also possible contributions by equilibrium concentrations of $\mathrm{Fe}$ (II) and sulfide, which increase with decreasing $\mathrm{pH}$, are taken into account. The $\mathrm{pH} 8$ supernatant was titrated to $\mathrm{pH} 6$ and back to 8 ; the $\mathrm{pH} 6$ supernatant was titrated to $\mathrm{pH}$ 8. No significant difference between the two blanks was found, so for blank corrections the data were used from the blank titration performed down to $\mathrm{pH} 6$ after filtration of the suspension at $\mathrm{pH} 8$.

The $\mathrm{pH}$ of the suspension in the airtight $500 \mathrm{~mL}$ titration cell was controlled via an automated system, consisting of a Metrohm $736 \mathrm{GP}$ Titrino for base delivery $([\mathrm{NaOH}]=0.01 \mathrm{M})$ and a Metrohm 685 Dosimat for acid delivery $([\mathrm{HCl}]=0.1 \mathrm{M})$ coupled to a PC equipped with TiNet 2.4 software. To minimize local $\mathrm{OH}^{-}$or $\mathrm{H}^{+}$excess, acid and base were added at a rate of $0.05 \mathrm{~mL} \mathrm{~min}{ }^{-1}$. Throughout the experiment, $\mathrm{pH}$ was measured using a Metrohm 6.0233.100 combined LL $\mathrm{pH}$ glass electrode incorporated in the titration cell. Before use, the electrode was calibrated in CALITECH $\mathrm{pH} \mathrm{4,} \mathrm{7,} \mathrm{and} 10$ buffers traceable to NIST (National Institute of Standards and Technology) standards, and after use, the electrode was checked for drift in the $\mathrm{pH}$ 7 buffer. The drift of the electrode during a run was always less than $0.01 \mathrm{pH}$ unit. The $\mathrm{pH}$ of the suspension had been adjusted to an initial value of 8 by base addition before the potentiometric titration was started. Titrations were performed by decreasing the $\mathrm{pH}$ to a value of 6 and then back to a value of 8 . After each acid or base addition, the $\mathrm{pH}$ reading was allowed to stabilize before the next addition. A potential drift of less then $0.5 \mathrm{mV} \min ^{-1}$ was used as a criterion for stable readings, or a maximum equilibration time of $30 \mathrm{~min}$ was allowed if a stable reading was not reached.

The proton balance on the solid surface, $Q$ (in $\mathrm{mol} / \mathrm{g} \mathrm{FeS}$ ), was calculated from the potentiometric acid titration by correcting the total proton balance in the system $\left(C_{A}-C_{B}\right)$ for all matrix impurities and dissolution of the solid as follows:

$$
Q=\frac{C_{A}-C_{B}-Q_{\text {blank }}-\left[\mathrm{H}^{+}\right]_{c}}{N}
$$

where $C_{A}$ and $C_{B}$ are acid and base concentrations added per liter, $N$ is the amount of solid (in $\mathrm{g} \mathrm{L}^{-1}$ ). $Q_{\text {blank }}$, in $\mathrm{M}$, is the proton balance as a function of $\mathrm{pH}$ derived from the blank potentiometric titration as follows (Stumm, 1991):

$$
Q_{\text {blank }}=C_{A}-C_{B}+\left[\mathrm{OH}^{-}\right]-\left[\mathrm{H}^{+}\right]
$$

$Q_{\text {blank }}$ includes all protolytic components in the matrix such as ammonia and aqueous bisulfide. The $\mathrm{H}^{+}$concentration is calculated from the measured $\mathrm{pH}$ and $\left[\mathrm{OH}^{-}\right]=\mathrm{K}_{\mathrm{w}}\left\{\mathrm{H}^{+}\right\}^{-1} \gamma_{\mathrm{OH}}^{1}$. The term $\left[\mathrm{H}^{+}\right]_{\mathrm{c}}$ in Eqn. 15 describes the proton consumption by solid dissolution depending on $\mathrm{pH}$. This correction of $Q$ is necessary because of the high solubility of $\mathrm{FeS}$, especially towards lower $\mathrm{pH}$ values (cf. Schulthess and Sparks, 1986; Bayens and Bradbury, 1997). To derive an expression for $\left[\mathrm{H}^{+}\right]_{\mathrm{C}}$, a mass balance relating the consumed protons to the produced $\mathrm{Fe}(\mathrm{II})$ and $\mathrm{S}(-\mathrm{II})$ species needs to be made (Eqn. 17):

$$
\left[\mathrm{H}^{+}\right]_{\mathrm{c}}=\left[\mathrm{HS}^{-}\right]_{\mathrm{p}}+2\left[\mathrm{H}_{2} \mathrm{~S}(\mathrm{aq})\right]_{\mathrm{p}}+\left[\mathrm{FeSH}^{+}\right]_{\mathrm{p}}+2\left[\mathrm{Fe}(\mathrm{SH})_{2}^{0}\right]_{\mathrm{p}}(17)
$$

For each bisulfide and $\mathrm{FeSH}^{+}$complex produced during dissolution, one proton is consumed; for each $\mathrm{H}_{2} \mathrm{~S}(\mathrm{aq})$ and $\mathrm{Fe}(\mathrm{SH})_{2}^{0}$ produced, two protons are consumed. Combining mass balances 12 and 17 results in 18:

$$
\begin{gathered}
{\left[\mathrm{H}^{+}\right]_{\mathrm{c}}=\left[\mathrm{Fe}^{2+}\right]-\left[\mathrm{Fe}^{2+}\right]_{\mathrm{i}}+\left[\mathrm{H}_{2} \mathrm{~S}(\mathrm{aq})\right]-\left[\mathrm{H}_{2} \mathrm{~S}(\mathrm{aq})\right]_{\mathrm{i}}+\left[\mathrm{Fe}(\mathrm{SH})^{+}\right]} \\
-\left[\mathrm{Fe}(\mathrm{SH})^{+}\right]_{\mathrm{i}}+\left[\mathrm{Fe}(\mathrm{SH})_{2}^{0}\right]-\left[\mathrm{Fe}(\mathrm{SH})_{2}^{0}\right]_{\mathrm{i}}
\end{gathered}
$$

where suffix c indicates consumed, $\mathrm{p}$ indicates produced by dissolution, and $\mathrm{i}$ indicates initially in solution, i.e., at $\mathrm{pH} 8$. Converting mass balance 18 to include activities for all species and filling in Eqns. 6, 8, 9, and 13, an expression for $\left[\mathrm{H}^{+}\right]_{\mathrm{c}}$ can be derived as follows:

$$
\begin{aligned}
& \frac{\left\{\mathrm{H}^{+}\right\}_{\mathrm{c}}}{{ }^{\gamma} \mathrm{H}}=\frac{\left\{\mathrm{Fe}^{2+}\right\}}{{ }^{\gamma} \mathrm{Fe}}-\frac{\left\{\mathrm{Fe}^{2+}\right\}_{\mathrm{i}}}{{ }^{\gamma} \mathrm{Fe}}+\frac{\left\{\mathrm{H}_{2} \mathrm{~S}(\mathrm{aq})\right\}}{{ }^{\gamma} \mathrm{H} 2 \mathrm{~S}}-\frac{\left\{\mathrm{H}_{2} \mathrm{~S}(\mathrm{aq})\right\}_{\mathrm{i}}}{{ }^{\gamma} \mathrm{H} 2 \mathrm{~S}}+\frac{\left\{\mathrm{FeHS}^{+}\right\}}{{ }^{\gamma} \mathrm{FeSH}} \\
& -\frac{\left\{\mathrm{FeHS}^{+}\right\}_{\mathrm{i}}}{{ }^{\gamma} \mathrm{FeSH}}+\frac{\left\{\mathrm{Fe}(\mathrm{SH})_{2}^{0}\right\}}{{ }^{\gamma} \mathrm{Fe}(\mathrm{SH}) 2}-\frac{\left\{\mathrm{Fe}(\mathrm{SH})_{2}^{0}\right\}_{\mathrm{i}}}{{ }^{\gamma} \mathrm{Fe}(\mathrm{SH}) 2}
\end{aligned}
$$

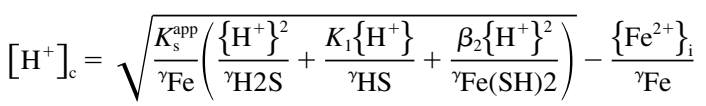

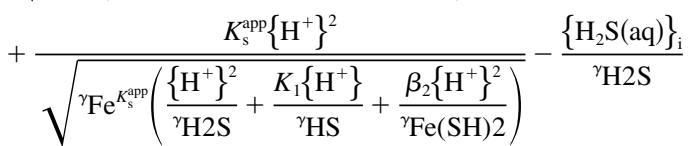

$$
\begin{aligned}
& +\frac{\beta_{1}\left\{\mathrm{H}^{+}\right\}}{{ }^{\gamma} \mathrm{FeSH}}-\frac{\left\{\mathrm{FeSH}^{+}\right\}_{\mathrm{i}}}{{ }^{\gamma} \mathrm{FeSH}} \\
& +\frac{\beta_{2} K_{\mathrm{s}}^{\mathrm{app}}\left\{\mathrm{H}^{+}\right\}^{2}}{{ }^{\gamma} \mathrm{Fe}(\mathrm{SH}) 2 \sqrt{{ }^{\gamma} \mathrm{Fe}^{\mathrm{K}_{\mathrm{s}}^{\mathrm{app}}}\left(\frac{\left\{\mathrm{H}^{+}\right\}^{2}}{{ }^{\gamma} \mathrm{H} 2 \mathrm{~S}}+\frac{K_{1}\left\{\mathrm{H}^{+}\right\}}{{ }^{\gamma} \mathrm{HS}}+\frac{\beta_{2}\left\{\mathrm{H}^{+}\right\}^{2}}{{ }^{\gamma} \mathrm{Fe}(\mathrm{SH}) 2}\right)}} \\
& -\frac{\left\{\mathrm{Fe}(\mathrm{SH})_{2}^{0}\right\}_{\mathrm{i}}}{{ }^{\gamma} \mathrm{Fe}(\mathrm{SH}) 2}
\end{aligned}
$$

where where $\left\{\mathrm{Fe}^{2+}\right\}_{\mathrm{i}}=10^{-5.45},\left\{\mathrm{H}_{2} \mathrm{~S}(\mathrm{aq})\right\}_{\mathrm{i}}=10^{-6.51},\left\{\mathrm{FeSH}^{+}\right\}_{\mathrm{i}}$ $=10^{-5.95}$, and $\left\{\mathrm{Fe}(\mathrm{SH})_{2}^{0}\right\}_{\mathrm{i}}=10^{-9.9}$. With this expression (Eqn. 19), the amount of protons consumed can be calculated at any $\mathrm{pH}$ for all ionic strengths by dissolution of synthetic FeS. All activity corrections were calculated using the Davies equation. In the $\mathrm{pH}$ range of the experiments, the increase in solution species due to dissolution of the solid has a negligible effect on the ionic strength. Thus, the activity coefficients remain constant up to two decimals over the $\mathrm{pH}$ ranges of all experiments.

\section{RESULTS}

\subsection{Solubility}

Fig. 1 shows the total dissolved $\mathrm{Fe}(\mathrm{II}), \log \left[\mathrm{Fe}(\mathrm{aq})_{\mathrm{T}}\right]$, with $\mathrm{pH}$. The total dissolved iron, including both free and complexed $\mathrm{Fe}(\mathrm{II})$, was measured in aliquots taken during the titra- 


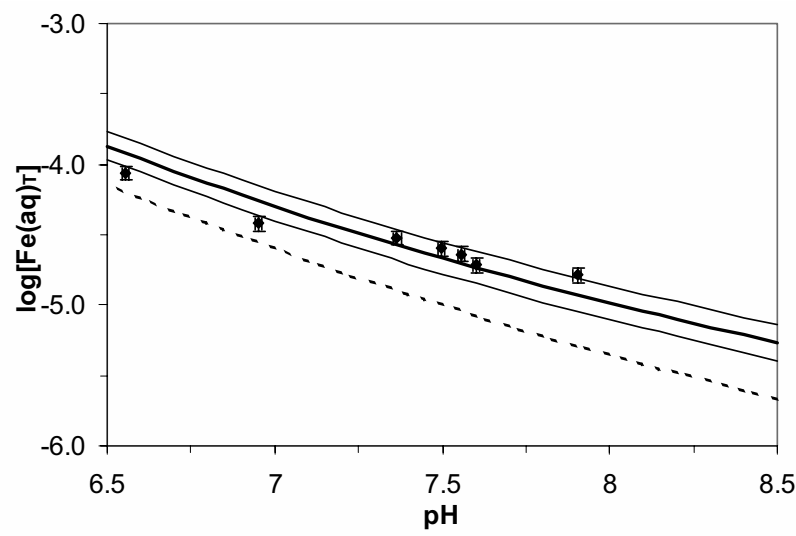

Fig. 1. Total dissolved $\mathrm{Fe}(\mathrm{II}), \log \left[\mathrm{Fe}(\mathrm{aq})_{\mathrm{T}}\right]$, plotted vs. pH. Filled diamonds are measured values, the dotted line is the predicted total dissolved iron using the solubility $K_{\mathrm{s}}^{*}=10^{+3.98}$ (Davison et al., 1999), and the solid lines using $K_{\mathrm{s}}^{\text {app }}=10^{+4.87 \pm 0.27}$ (this work), fitting the $\log \left[\mathrm{Fe}(\mathrm{aq})_{\mathrm{T}}\right]$ data with $R^{2}=0.90$ (see sections 2.2 and 3.1).

tions. The total dissolved iron increased with decreasing $\mathrm{pH}$ due to dissolution of the solid. Equation 14 is the expression for the total dissolved iron as a function of $\mathrm{pH}$. The dotted line in Figure 1 describes the calculated total dissolved iron as a function of $\mathrm{pH}$ if it is assumed that (i) equilibrium is established between all solution species and with the solid, (ii) $\mathrm{H}_{2} \mathrm{~S}$ degassing is insignificant, (iii) $\mathrm{FeS}$ is stoichiometric (cf. Lennie and Vaughan, 1996), and (iv) FeS dissolves congruently according to reaction 1 with an apparent solubility constant of $K_{\mathrm{s}}^{\text {app }}$ $=10^{+3.98 \pm 0.12}$ (Davison et al., 1999). To fit the measured total dissolved iron concentrations, the value for $K_{\mathrm{s}}^{\mathrm{app}}$ was varied by trial and error. The best fit was found with $K_{\mathrm{s}}^{\text {app }}$ $=10^{+4.87 \pm 0.27}$, fitting the total dissolved iron data with an $R^{2}$ of 0.90 , resulting in the band of solid lines in Figure 1. This is higher than the value recalculated from Davison et al. (1999).

\subsection{Potentiometric Titrations}

The proton balances from the acid-base titrations were calculated through Eqn. 15, that is, they have been corrected for proton consumption by: (i) protolytic components in solution, (ii) the dissociation of water, (iii) solid dissolution using $K_{\mathrm{s}}^{\text {app }}$ $=10^{+4.87}$, and (iv) aqueous iron-sulfide complexation. Therefore, the surface protonation data, plotted as $Q$ in $\mathrm{mmol} / \mathrm{g} \mathrm{FeS}$ vs. $\mathrm{pH}$ as circle, triangle, and square symbols in Figure $2 \mathrm{a}$ and $\mathrm{b}$, represent the proton balances at the surface of disordered mackinawite at $0.053,0.0078$, or $0.103 \mathrm{M}$ ionic strength. Since these surface protonation curves have a common inflection point at $\mathrm{pH}$ value $7.5 \pm 0.2$, they have been shifted vertically so as to intersect each other and the $Q=0 \mathrm{mmol} \mathrm{g}^{-1} \mathrm{FeS}$ at the common inflection point. This common inflection point is assumed to be the $\mathrm{pH}$ value where the surface has a zero proton charge $\left(\mathrm{pH}_{\mathrm{PZC}}\right)$. Thus, at $\mathrm{pH}>\sim 7.5$, the surface increasingly becomes negatively charged, approaching saturation at high $\mathrm{pH}$ values. At $\mathrm{pH}<\sim 7.5$, the surface becomes increasingly positively charged until the surface approaches saturation at $\mathrm{pH}$ $\approx 6.5$ (Fig. 2a and b). Significant hysteresis was observed between consecutive acid and base titrations (data not shown); the base titration was shifted as much as $1.5 \mathrm{pH}$ unit higher than the acid titration.

\section{DISCUSSION}

\subsection{Solubility}

The solubility of FeS was determined to correct for dissolution effects during the acid-base titrations. The derived apparent solubility constant is $K_{\mathrm{s}}^{\mathrm{app}}=\left\{\mathrm{Fe}^{2+}\right\} \cdot\left\{\mathrm{H}_{2} \mathrm{~S}(\mathrm{aq})\right\} \cdot\left\{\mathrm{H}^{+}\right\}^{-2}$ $=10^{+4.87 \pm 0.27}\left(25^{\circ} \mathrm{C}\right)$. Benning et al. (2000) noted that the solubility of $\mathrm{FeS}$ in the important neutral and alkaline $\mathrm{pH}$ range $(6$ $>\mathrm{pH}<8.5)$ was poorly constrained and found values for $K_{\mathrm{s}}^{\mathrm{app}}$ at $80^{\circ} \mathrm{C}$ of $10^{+6.55}(\mathrm{pH} 8.15)$ and $10^{+7.31}(\mathrm{pH} 7.39)$. The divergence observed at $25^{\circ} \mathrm{C}$ and $\mathrm{pH} 6$ to 8 for $K_{\mathrm{s}}^{\text {app }}$ in the present study is, therefore, well within the uncertainty observed at $80^{\circ} \mathrm{C}$ at $\mathrm{pH} 7$ to 8. Benning et al. (2000) also noted that the variation in their measurements in this $\mathrm{pH}$ range suggested that a detailed study of $\mathrm{FeS}$ solubility at neutral to alkaline $\mathrm{pH}$ was urgently required. Although not a detailed study, the present solubility determination for $\mathrm{FeS}$ is the first to result in a designation of $K_{\mathrm{s}}^{\text {app }}$ at neutral to alkaline $\mathrm{pH}$.

The apparent solubility constant derived here is higher than the $20^{\circ} \mathrm{C}$ solubility constant $K_{\mathrm{s}}^{*}=10^{+3.98 \pm 0.12}$ recalculated from Davison et al. (1999) (Fig. 1). Preparation methods have often been named as controlling bulk characteristics as, for example, particle size (cf. Morse et al., 1987; Davison, 1991; Wolthers et al., 2003), and consequently, may control FeS reactivity and solubility. Furthermore, Wolthers et al. (2003) have shown that FeS may contain variable amounts of structurally incorporated water molecules, a property that is likely to influence solubility.

The total dissolved iron vs. $\mathrm{pH}$ plot presented here (Fig. 1) shows a $\mathrm{pH}$ dependence of $\log \left[\mathrm{Fe}(\mathrm{aq})_{\mathrm{T}}\right]$ with an approximate average slope of -0.5 when fitted linearly. When reaction 1 controls FeS solubility in the $\mathrm{pH} 6$ to 8 range, then the slope in Figure 1 would be -1 , assuming that $\left\{\mathrm{Fe}^{2+}(\mathrm{aq})\right\}$ is equal to $\left\{\mathrm{H}_{2} \mathrm{~S}(\mathrm{aq})\right\}$. Similarly, when reactions 1 and 2 control FeS solubility, then the slope is -0.5 . Furthermore, if the complexation reactions 4 or 5 would control FeS solubility, then the slope would be -1 or -2 , respectively. However, while the average slope observed is -0.5 , a close inspection of Figure 1 shows that the slope tends to level off towards zero with increasing $\mathrm{pH}$. In fact, this leveling off with $\mathrm{pH}$ suggests that the aqueous $\mathrm{FeS}$ cluster complex forms an important part of the total dissolved iron with increasing $\mathrm{pH}$, because its formation is $\mathrm{pH}$ independent (Rickard and Luther, 1997):

$$
\mathrm{FeS}(\mathrm{s}) \rightarrow \mathrm{FeS}(\mathrm{aq})
$$

Furthermore, the size of the aqueous FeS cluster complex is too small to allow removal by filtration through the $0.2 \mu \mathrm{m}$ filter discs used (cf. Wolthers et al., 2003). Therefore, from Figure 1, it is concluded that the solubility is not simply controlled by one of the reactions $1,2,4$, or 5 , and that the dominant dissolution reaction changes with $\mathrm{pH}$. Determining the dissolution mechanism or the generic solubility product for $\mathrm{FeS}$ in the neutral to alkaline $\mathrm{pH}$ range is beyond the scope of the present work. The determined $K_{\mathrm{s}}^{\mathrm{app}}$ allows correction for proton consumption during the potentiometric titration, and thus serves the present purpose. 

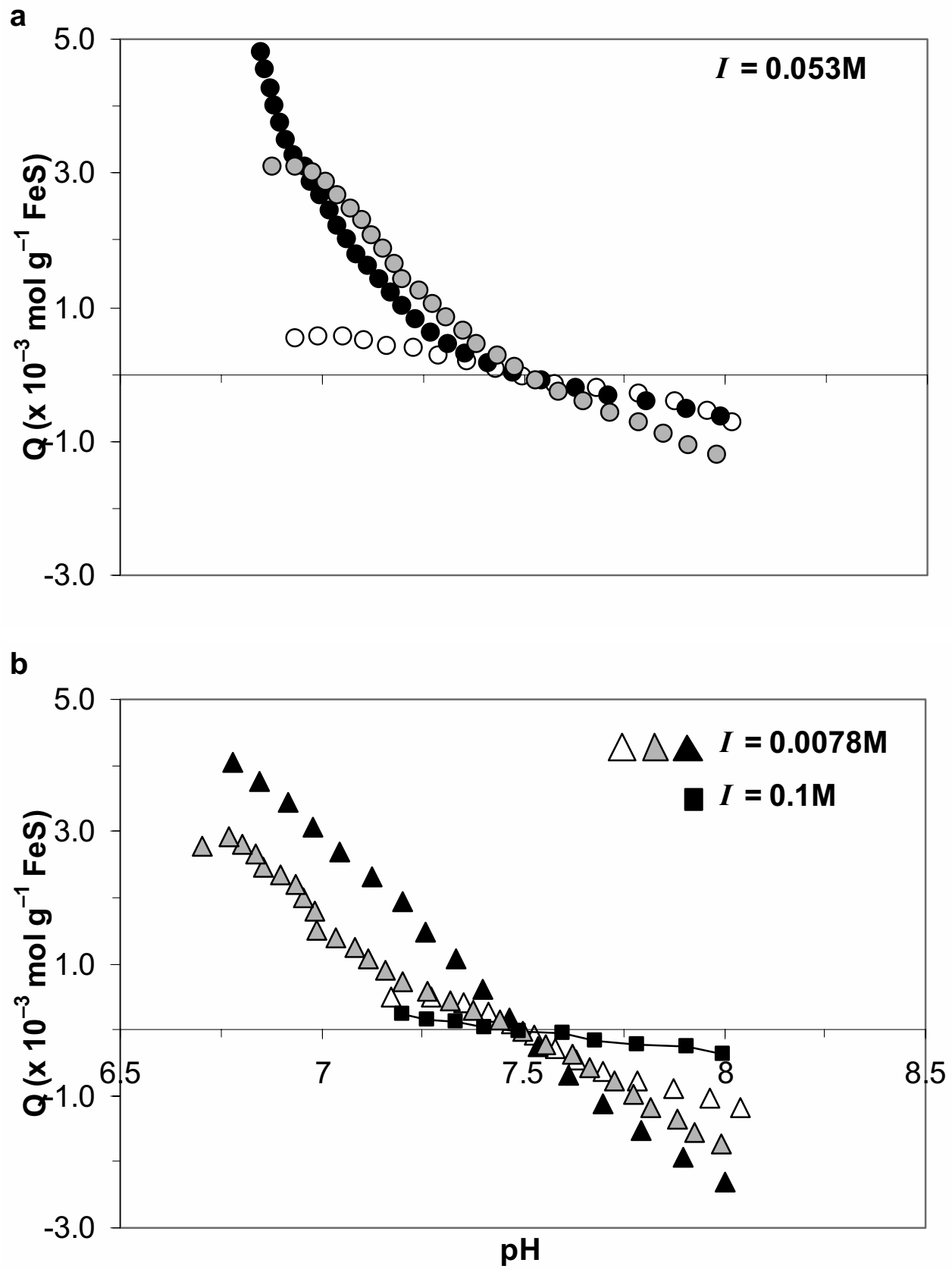

Fig. 2. Proton balances from the disordered mackinawite surface titrations: (a) experimental proton balance $Q$ calculated according to Eqn. 2 from the titrations performed at $I=0.053 \mathrm{M}$ plotted vs. pH; and (b) $Q$ calculated from $I=0.0078 \mathrm{M}$ (open triangles) and $I=0.103 \mathrm{M}$ (filled squares, duplicate experiment plotted as one) titrations vs. pH.

\subsection{Surface Charge}

Titrations performed with suspensions of in situ precipitated stoichiometric iron(II) monosulfide have the advantage of minimizing surface oxidation. The conditions can be kept as oxygen-free as possible, and any treatment such as drying, which may alter the surface characteristics, is avoided (Morse and Arakaki, 1993; Herbert et al., 1998). The precipitation process results in very small particles, implying a large surface area that will closely simulate naturally occurring disordered mackinawite. It is expected that titrations performed in solutions with increasing ionic strengths give an increasing slope of the resulting $Q$ vs. $\mathrm{pH}$ curve (cf. Dzombak and Morel, 1990). However, the $Q$ vs. $\mathrm{pH}$ curves in Figure 2a and $\mathrm{b}$ do not show this trend. The precipitation of FeS occurs through heterogeneous nucleation, forming a mixture of two end-member phases with different long-range crystallographic ordering and different sizes, followed by growth including lattice contractions and a change in relative proportions of the end-member phases (Wolthers et al., 2003). The variability of the titration data may be reflecting this complex stochastic precipitation process. 
The trend from the surface protonation curves is nevertheless reproducible, showing an increase in surface charge with decreasing $\mathrm{pH}$ and reaching saturation towards high and low $\mathrm{pH}$ (Fig. 2a and b). When only one symmetrical inflection is observed in a solid titration curve, as with hydrous ferric oxide titrations, then the net surface protonation curve represents the protonation of one kind of active surface site. The $\mathrm{pH}$ value of this inflection point is assumed to be the $\mathrm{pH}_{\mathrm{PZC}}$. Moreover, in the numerous $\mathrm{FeS}$ syntheses performed during this study, the supernatant $\mathrm{pH}$ was observed to be stable within several minutes after precipitation at a value varying between 7.4 and 7.8. For carbonates, it has been shown that when solubility equilibrium is attained, the electro neutrality condition applies to $\mathrm{pH}$ and the solutes in equilibrium with the solid carbonates ("proton condition;" cf. Stumm and Morgan, 1981; Van Cappellen et al., 1993). Stumm and Morgan postulated that under these conditions, the mineral suspension must have zero surface charge. Extrapolating the "proton condition" to iron sulfides, the observations of a stable supernatant $\mathrm{pH}$ support a $\mathrm{pH}_{\text {PZC }}$ $\sim 7.5$. If the surface charge is solely acquired by protonation and deprotonation, the point of zero charge is pristine and therefore equal to the $\mathrm{pH}_{\text {PZNPC }}$ (Dzombak and Morel, 1990). The FeS surface titrations were performed within a complex solution and adsorption of other potential determining ions cannot be ruled out. Therefore, the common inflection point of the surface protonation curves is referred to as the $\mathrm{pH}_{\mathrm{PZC}}$.

Significant hysteresis was observed between consecutive acid and base titrations; the base titration was shifted as much as $1.5 \mathrm{pH}$ units higher than the acid titration. For hydrous ferric oxide, similar hysteresis is observed. Sorption and desorption on oxides are governed by two-step kinetics: a fast initial step (min) followed by a much slower second step (Dzombak and Morel, 1990). The second step is generally thought to result from exchange within the interior of oxide particles, causing hysteresis between consecutive acid and base titrations. Rapid titrations should therefore be employed, that is, slow enough for the first step to reach equilibrium while fast enough to avoid the second step (cf. Charlet et al., 1990). Even with fast acid-base titrations, hysteresis is observed. In particular, hysteresis is reported for amorphous oxides where the second step is faster than for more crystalline oxides (Dzombak and Morel, 1990). The fact that similar hysteresis is observed for FeS suggests that similar two-step kinetics govern the surface protonation and deprotonation reactions.

Widler and Seward (2002) performed the only previously reported potentiometric titration on the surface of mackinawite. They obtained a similarly shaped trend with one inflection, shifted to lower $\mathrm{pH}$ compared to Figure $2 \mathrm{a}$ and $\mathrm{b}$ for hydrothermally synthesized and hence more crystalline mackinawite. They estimated the $\mathrm{pH}_{\mathrm{PZC}}$ to be 2.9 from one blank-uncorrected curve. However, no surface deprotonation was found in the base titration, that is, the surface protonation was irreversible, and they observed a surface protonation in zero ionic strength solutions only. These observations seem to be inconsistent with the data presented here and data for other mineral surfaces. In an electrokinetic study performed on a range of crystalline metal sulfides, although not on mackinawite, Bebié et al. (1998) estimated that the isoelectric point $\left(\mathrm{pH}_{\text {i.e.p. }}\right.$, the point of zero charge in the shearing plane of the moving particle; Sposito, 1984) for all studied metal sulfides lies below
$\mathrm{pH}$ 3.3. In general, more alkaline points of zero charge, such as $\sim 8.5$ for $\mathrm{ZnS}$ from Rönngren et al. (1991), 8.5 for PbS from Sun et al. (1991), and 7.7 for CdS from Park and Huang (1987) are thought to be affected by oxidation (Bebié et al., 1998; Widler and Seward, 2002), and the effect of slight oxidation has been shown to shift the $\mathrm{pH}_{\mathrm{PZC}}$ of pyrite (Bebié et al., 1998). Although it could be argued that the data reported here have been affected by oxidation as well, it should be noted that continuous dissolution of $\mathrm{FeS}$ during the titration renews the FeS surface while also increasing the $\mathrm{S}(-\mathrm{II})$ concentration in solution. The dissolved S(-II) may be more reactive towards $\mathrm{O}_{2}$ than the FeS surface and further ensure anoxia. Therefore, it is assumed that the reproducible trends observed and the $\mathrm{pH}_{\mathrm{PZC}}$ estimated are accurate and unaffected by oxidation. Moreover, discrepancies between proton titration data and electrokinetic data have been reported for other minerals, for example, silica (Gabriel et al., 2001). The zeta potential, calculated from electrophoretic measurements, reflects the charge of the moving particle at the shearing plane, located in the diffuse layer at a distance from the surface (Sposito, 1984; Stumm, 1991). In contrast, from potentiometric titration data, the charge at the surface is calculated. Additionally, the FeS was precipitated in situ, and other components of the reactants, most notably sulfate, were not removed. The sorption of such components on the surface will affect the protonation/deprotonation and resulting surface charge and can shift the resulting $\mathrm{pH}_{\mathrm{PZC}}$. For example, Bebié et al. (1998) showed significant changes in, and indeed charge reversals of, the surface charge $\mathrm{pH}$ dependence with the addition of $\mathrm{Fe}$ (II) to a pyrite suspension. Hence, a difference between the values for the $\mathrm{pH}_{\text {i.e.p. }}$ referred to above and the $\mathrm{pH}_{\mathrm{PZC}}$ reported here for the same, though less crystalline, mineral surface is to be expected.

Features that might affect the $\mathrm{pH}_{\mathrm{PZC}}$ of disordered mackinawite more strongly than that of crystalline mackinawite are proton diffusion and aging. Proton diffusion from the surface into the solid, for example, in between the tetrahedral sheets as indicated by the hysteresis of the acid and base titrations, leads to an overestimated surface charge since the surface explored by protons increases with time (Dzombak and Morel, 1990). Thus, the $\mathrm{pH}_{\mathrm{PZC}}$ will be shifted to a more alkaline $\mathrm{pH}$ due to proton diffusion. This may be expected to be important for FeS, since FeS has been shown to contain intercalation of water, or possibly $\mathrm{OH}^{-}$, molecules betweenthe tetrahedral sheets (Wolthers et al., 2003). Significantly lower $\mathrm{pH}_{\mathrm{PZC}}$ values were reported for hydrous ferric oxide after long aging times (Prasad, 1976; Kuo and McNeal, 1984) with the possibility of transformation of hydrous ferric oxide to goethite. Similarly, $\mathrm{pH}_{\mathrm{PZC}}$ shifts to lower values have been observed for silica surfaces (Foissy and Persello, 1998). The shifts for silica were explained by an increase of surface-site acidity with polymerization and structuration (Strazhesko et al., 1974; Milonjić, 1987; Foissy and Persello, 1998). Possibly, the acidity of sulfide surface groups increases with crystallinity as well. It is proposed here that the pristine FeS surface has a $\mathrm{pH}_{\mathrm{PZC}} \sim 7.5$. The surface charge of $\mathrm{FeS}$ will also be affected by the ratio of iron to sulfide in solution. Both are potential determining ions for the pristine FeS surface (e.g., Dekkers and Schoonen, 1994; Bebié et al., 1998). In natural environments, the $\mathrm{FeS}$ surface charge will further depend on the solution chemistry and cation or ligand adsorption. Future work aiming to resolve the existing dis- 


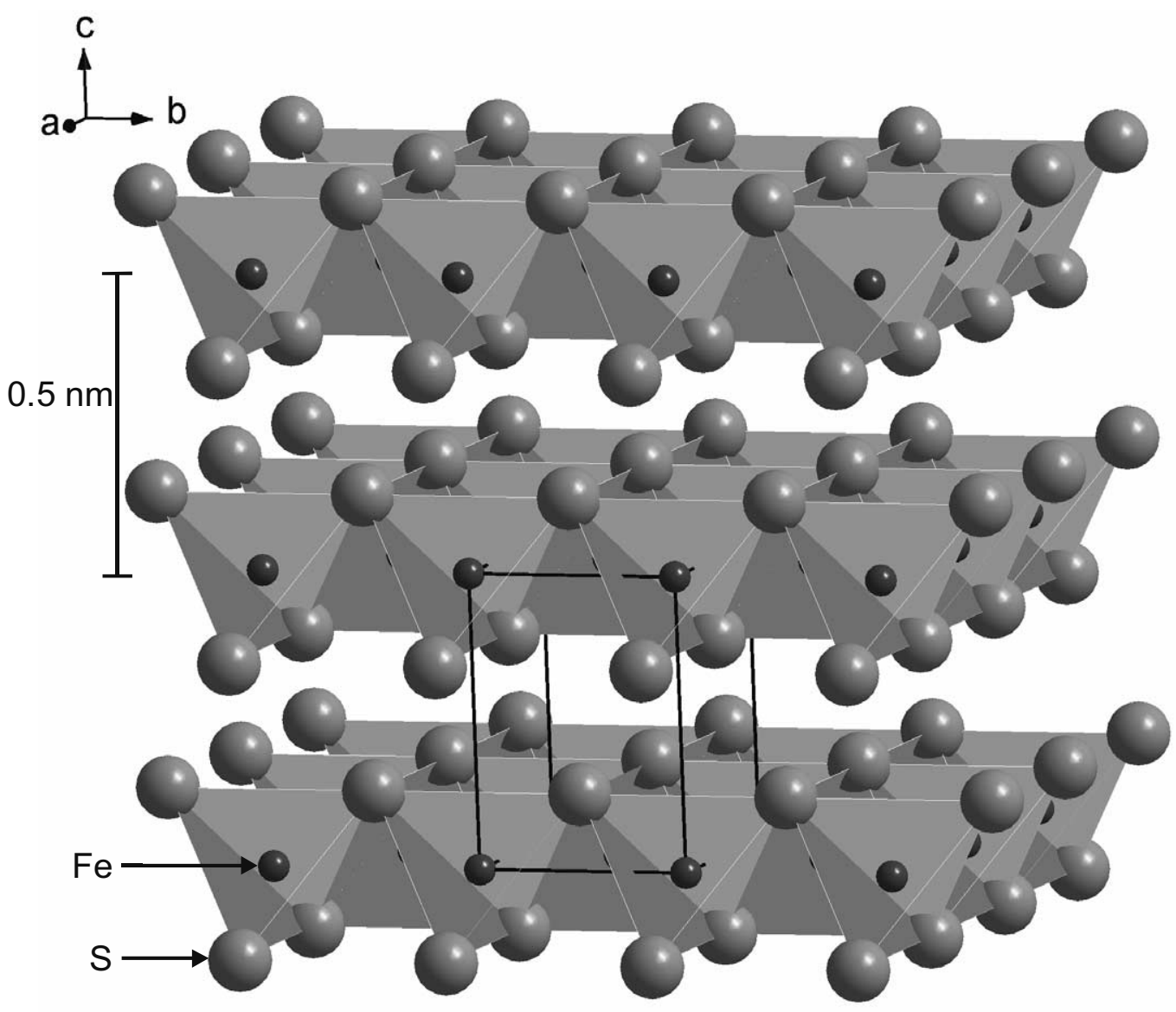

Fig. 3. Sketch of the mackinawite structure viewed from $\sim 30^{\circ}$ above the (001) plane. The tetragonal unit cell is indicated. The Fe-Fe bond length is $2.60 \AA$, which is extremely close to that of $\alpha$-iron and suggests significant Fe-Fe bonding. The Fe atoms are in square planar coordination and constitute the (001) plane of the structure. The sheets of $\mathrm{Fe}$ atoms are separated by $\sim 0.5 \mathrm{~nm}$, and the sheets are weakly held by Van der Waals bonding between the $\mathrm{S}$ atoms. The interstices between the sheets are potential sites for other molecules such as $\mathrm{H}_{2} \mathrm{O}$. The sketch shows open tetrahedra with $\mathrm{Fe}$ atoms in the centers and $\mathrm{S}$ atoms at the corners. Conventional ionic radii are used for clarity. The Fe-Fe bonding, the Fe-S covalent and S-S Van der Waals bonding make substantial changes to the effective atomic radii.

agreements on the point of zero charge of metal sulfides should encompass both potentiometric titrations and electrokinetic studies, as a function of iron to sulfide ratios, and focus on aging and exchange effects.

\subsection{Surface Reactive Sites}

At iron sulfide surfaces, two possible functional groups have previously been suggested: an iron(II) hydroxyl functional group, $\equiv \mathrm{FeOH}^{\mathrm{O}}$, and a sulfide functional group, $\equiv \mathrm{SH}^{\mathrm{O}}$ (Kornicker, 1988; Bebié et al., 1998). However, in solutions saturated with respect to $\mathrm{FeS}$, the aqueous $\mathrm{FeSH}^{+}$complex is dominant over the $\mathrm{FeOH}^{+}$complex at $\mathrm{pH}<\sim 10$. Thus, the $\mathrm{Fe}-\mathrm{SH}$ bond is expected to be favored over $\mathrm{Fe}-\mathrm{OH}$ bond. Therefore, it is proposed that the hydrated disordered mackinawite surface can be described by mono-coordinated and tricoordinated sulfur sites at the surface reactive sites rather than the tricoordinated iron and sulfur sites from a truncated mackinawite lattice.

Analogous to the multisite complexation model for metal (hydr)oxides (Hiemstra et al., 1996), a model describing the proton affinity characteristics of the FeS reactive surface groups can be developed based on crystal structural considerations. At a local level, the structure of disordered mackinawite is similar to the layered structure of crystalline mackinawite, as shown by XRPD data (Wolthers et al., 2003). In each layer $\mathrm{FeS}_{4}$ tetrahedra are linked by edge sharing to four neighboring tetrahedra and by corner sharing to four neighboring tetrahedra (Fig. 3). The Fe-S distance is $2.230 \AA$ and the S-Fe-S angle is that of a regular tetrahedron, that is, $109^{\circ}$ (Taylor and Finger, 1970). Mackinawite has a platy habit, which is determined by two (001) faces, two (100), and two (010) faces - the latter two are in fact identical-and it is assumed that disordered mackinawite consists of nano-sized crystals of the same habit (Wolthers et al., 2003). According to Wolthers et al. (2003), the dominant $(\sim 80 \%)$ crystal size in freeze-dried FeS is $7.4 \times 7.4$ $\times 2.9 \mathrm{~nm}$. Assuming a perfectly platy crystal with these dimensions, this crystal will have two (001) faces consisting of $324\left(\mathrm{Fe}_{4} \mathrm{~S}\right)$ surface groups each, and two (100) and two (101) faces with zero $\left(\mathrm{Fe}_{4} \mathrm{~S}\right), 90\left(\mathrm{Fe}_{3} \mathrm{~S}\right), 5\left(\mathrm{Fe}_{2} \mathrm{~S}\right)$, and $100(\mathrm{FeS})$ 
surface groups each. The $\left(\mathrm{Fe}_{4} \mathrm{~S}\right)$ are coordinatively saturated and will not protonate; the $\left(\mathrm{Fe}_{2} \mathrm{~S}\right)$ are insignificant in amount compared to the $\left(\mathrm{Fe}_{3} \mathrm{~S}\right)$ and $(\mathrm{FeS})$ groups. The latter two therefore determine the surface reactivity of a perfectly platy crystal and as a close approximation, determine the surface reactivity of any FeS surface. The ratio of the concentrations of these two groups is approximately one to one. The overall reactive-site density is 4.0 sites $\mathrm{nm}^{-2}$, for only the reactive (100) and (010) edge faces it is 9.1 sites $\mathrm{nm}^{-2}$.

Hiemstra et al. (1996) showed that, for stable ionic solids, the charge distribution over surface groups can be described using Pauling's bond valence theory (Pauling, 1939; Pauling, 1960), even though the actual charge will deviate from the charge predicted by this theory. The deviation will be stronger for disordered mackinawite, a solid with dominantly covalent bonds (Pauling, 1970). Nevertheless, Pauling's bond valence theory will be used here to estimate the average charge distribution at the surface of disordered mackinawite. The bond valence is +0.5 for each iron and -0.5 for each sulfur, and thus the terminal mono-coordinated sulfur has a partial charge of -1.5 , that is, -2 for the charge of a sulfide ion plus +0.5 for the S-Fe bond. Accordingly, the sulfur atom coordinated to three $\mathrm{Fe}$ atoms has a valence charge of -0.5 . Upon hydrolysis, the terminal sulfur atoms will be protonated and the point of zero net proton charge (PZNPC) could be represented by two different configurations (Fig. $4 \mathrm{a}$ and $\mathrm{b}$ ) or a combination of both (Fig. 4c). Macroscopically, the three configurations in Figure 4 are equivalent.

The differences in partial charge for the mono-coordinated and tricoordinated sulfur sites will be expressed in different proton affinities. Hiemstra et al. (1996) have established a microscopic model for the surface of goethite. The goethite structure consists of double chains of edge-sharing octahedra. At the goethite surface, the mono-coordinated and tricoordinated oxygen proton-reactive sites have very different proton affinities (Hiemstra et al., 1996) due to their different degrees of coordinative saturation. Similarly, the mono-coordinated sulfur site is expected to be the more strongly acidic surface site and determines the acid-base properties of the $\mathrm{FeS}$ at $\mathrm{pH}$ $<$ PZNPC, while at higher $\mathrm{pH}$ the weaker acidic, tricoordinated sulfur is thought to determine surface charge changes. The hydrated sulfide surface can thus be represented by a uniform array of two types of surface sites with equal concentrations: one with a relatively higher proton affinity (the mono-coordinated sulfur site, also referred to below as the strong site) and one with a relatively lower proton affinity (the tricoordinated sulfur site, also referred to below as the weak site). This does not mean that all strong or weak surface sites must be microscopically identical, but rather that it is possible to assign macroscopically meaningful average properties to the sites.

\subsection{Surface Complexation Modeling}

In keeping with the fundamental concepts for all surface complexation models (Dzombak and Morel, 1990), it is assumed that (i) sorption reactions at the sulfide-water interface take place at specific coordination sites; (ii) sorption reactions on sulfides can be described quantitatively via mass law equations; (iii) surface charge results from the sorption reactions themselves; and (iv) the effect of surface charge on sorption can be taken into account by applying a correction factor derived from the electric double-layer theory to mass law constants for surface reactions. In the present case, the constant-capacitance model, a simplified form of the diffuse-layer model, is used to take into account the effect of surface charge on proton sorption.

A model describing the surface protonation with only one type of surface functional group was tested first but provided a poor fit compared to the model with two site types with different proton affinities. It is therefore concluded that the experimental data show the presence of at least two site types. This is consistent with the two types of theoretically deduced reactive sites (section 4.3). The two sites were assumed to protonate and deprotonate according to the following surface protonation reactions:

$$
\begin{gathered}
\equiv \mathrm{FeSH}^{0}+\mathrm{H}^{+} \leftrightarrow \equiv \mathrm{FeSH}_{2}^{+} \quad K_{\mathrm{st} 1}^{\mathrm{app}} \\
\equiv \mathrm{FeSH}^{0} \leftrightarrow \equiv \mathrm{FeS}^{-}+\mathrm{H}^{+} \quad K_{\mathrm{st} 2}^{\mathrm{app}} \\
\equiv \mathrm{Fe}_{3} \mathrm{SH}^{0}+\mathrm{H}^{+} \leftrightarrow \equiv \mathrm{Fe}_{3} \mathrm{SH}_{2}^{+} \quad K_{\mathrm{wk} 1}^{\mathrm{app}} \\
\equiv \mathrm{Fe}_{3} \mathrm{SH}^{0} \leftrightarrow \equiv \mathrm{Fe}_{3} \mathrm{~S}^{-}+\mathrm{H}^{+} \quad K_{\mathrm{wk} 2}^{\mathrm{app}}
\end{gathered}
$$

where $\equiv \mathrm{FeSH}^{0}$ is the neutral, strongly acidic mono-coordinated surface functional sulfide group that can protonate (reaction 21) and deprotonate (reaction 22), and $\equiv \mathrm{Fe}_{3} \mathrm{SH}^{\circ}$ is a neutral, weakly acidic tricoordinated sulfur site that can protonate (reaction 23) and deprotonate (reaction 24). $K_{\mathrm{stl}}^{\mathrm{app}}, K_{\mathrm{st2} 2}^{\mathrm{app}}$, $K_{\mathrm{wk} 1}^{\mathrm{app}}$, and $K_{\mathrm{wk} 2}^{\mathrm{app}}$ are the apparent surface acidity constants and are variable model parameters. In Wolthers et al. (2003), a specific surface area of $350 \mathrm{~m}^{2} \mathrm{~g}^{-1}$ for disordered mackinawite was proposed. Above, it was estimated that the total reactivesite density is 4.0 sites $\mathrm{nm}^{-2}$ and the relative site-density ratio $\equiv \mathrm{FeSH}^{0}: \equiv \mathrm{Fe}_{3} \mathrm{SH}^{0}$ is $\sim 1: 1$. From these data, the concentration of both reactive sites can be calculated: $\left[\equiv \mathrm{FeSH}^{0}\right]$ $=\left[\equiv \mathrm{Fe}_{3} \mathrm{SH}^{\mathrm{O}}\right] \approx 1.2 \mathrm{mmol} \mathrm{g}{ }^{-1} \mathrm{FeS}$. This was used as input into the surface complexation model. Modeling was performed throughout at the actual FeS concentrations.

A stepwise approach to modeling the surface protonation curve ( $Q$ vs. $\mathrm{pH}$ ) derived from the titration data was adopted by considering the simple, chemically reasonable model given by Eqns. 21 to 24 and finding a best fit by eye to the titration curve. In each step, the computer program MINEQL +4.06 was used to calculate the surface speciation from estimated $K$ values for Eqns. 21 to 24 using the constant capacitance model with a specific capacitance $k$ of $1 \mathrm{Fm}^{-2}$. From the modeled surface speciation, the surface charge was calculated as follows:

$$
\begin{aligned}
Q_{\mathrm{MINEQL}}=\left[\equiv \mathrm{FeSH}_{2}^{+}\right]+[\equiv & \left.\mathrm{Fe}_{3} \mathrm{SH}_{2}^{+}\right] \\
& -\left[\equiv \mathrm{FeS}^{-}\right]-\left[\equiv \mathrm{Fe}_{3} \mathrm{~S}^{-}\right]
\end{aligned}
$$

and compared to experimental values. Through trial and error, a set of apparent surface acidity constants for Eqns. 21 to 24 corresponding to the best fit of the experimental surface charge was obtained. In this way, the surface protonation data derived from a titration at $0.053 \mathrm{M}$ ionic strength was fitted with the MINEQL + model. The best fit to the surface protonation curve, shown as a solid line in Figure 5a, was obtained with the surface speciation given in Figure $5 \mathrm{~b}$ using the apparent surface acidity constants listed in Table 2 . The apparent surface acidity 

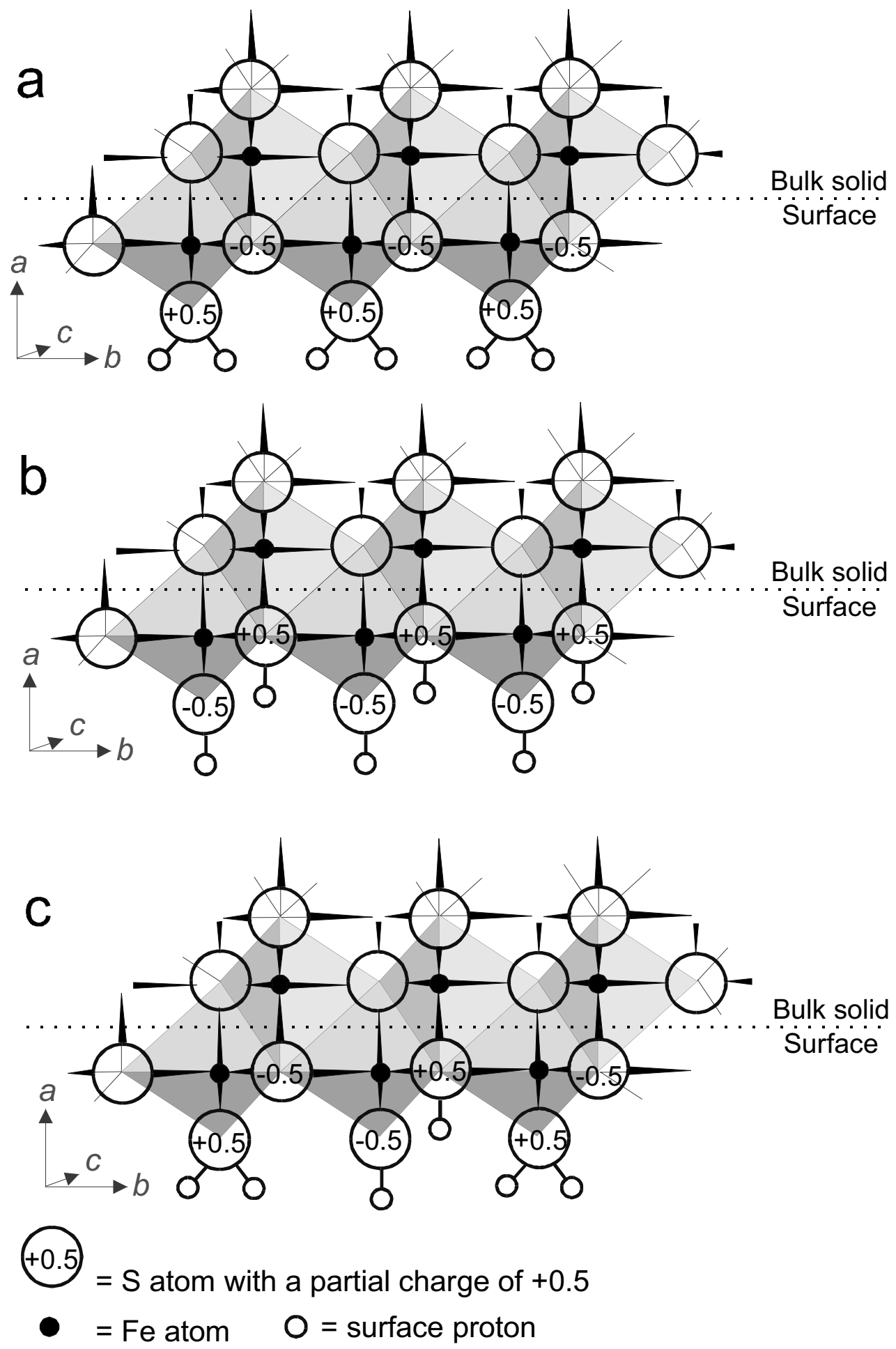

Fig. 4. Theoretical surface structural models at the point of zero net proton charge (PZNPC), viewed perpendicularly to the (001) plane, which is represented as tetrahedra (cf. Fig. 3). The representation of the sulfide surface is largely notional because relevant detailed surface spectroscopic data to support the presence of these various groups is lacking. The PZNPC might be represented by three configurations: (a) a double protonation of the mono-coordinated sulfur sites and no protonation of the tricoordinated sulfur sites; (b) single protonation of both site types; and (c) or a combination of (a) and (b). Macroscopically, the three configurations are equivalent. 


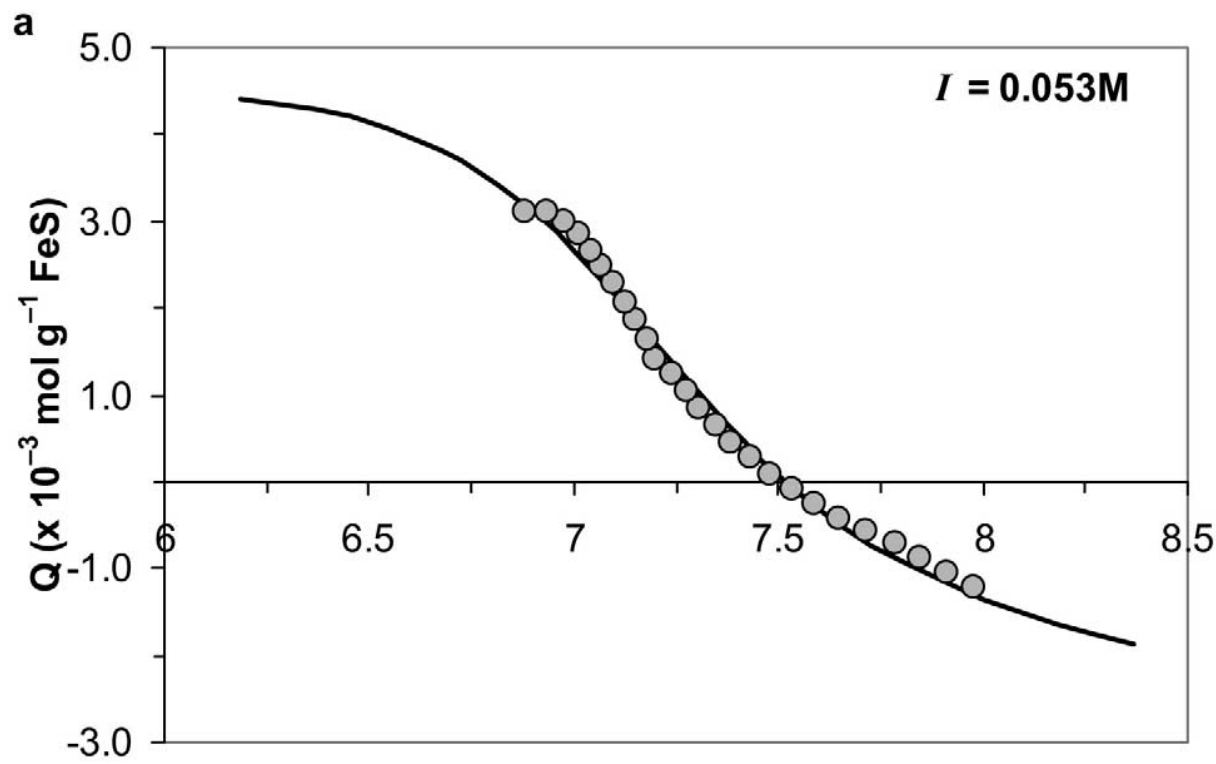

b

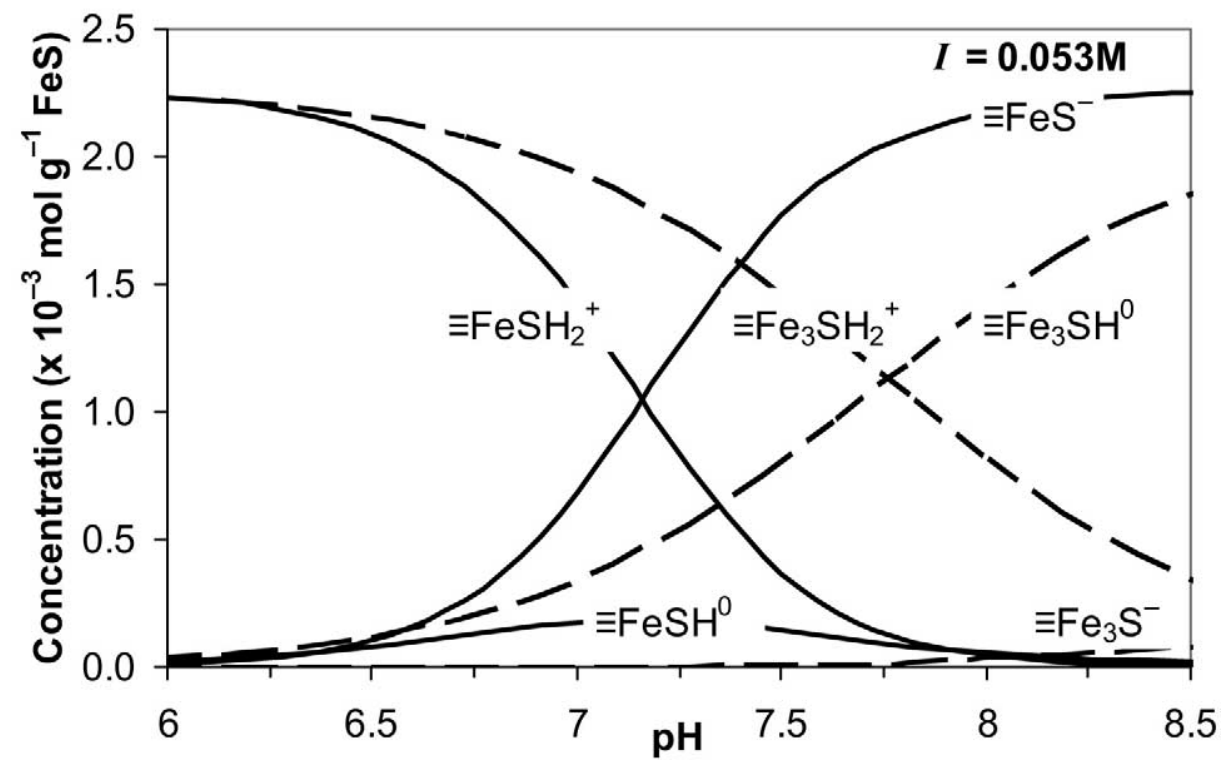

Fig. 5. Surface complexation model fit to an experimental proton balance at $I=0.053 \mathrm{M}$ : (a) experimental $Q$ (open circles) from an $I=0.053 \mathrm{M}$ titration fitted with $Q_{M I N E Q L}$ (solid line) from Eqn. 9; and (b) surface speciation calculated in MINEQL+ that sums up to $Q_{M I N E Q L}$ fitting the experimental data in (a).

constants Eqns. 21 to 24 are interdependent (Table 2). Within a certain range, equally good fits were obtained by simultaneously increasing one apparent surface acidity constant and decreasing another. This interdependence is reflected in the error given for the constants in Table 2 . The sensitivity of the model towards the specific capacitance was insignificant. An equally good fit could be obtained when increasing the $k$ from 1 to $30 \mathrm{~F} \mathrm{~m}^{-2}$. Insensitivity of the model to the specific capacitance means that the surface charge has no strong effect on the surface acidity constants. Furthermore, high $\left(>1 \mathrm{~F} \mathrm{~m}^{-2}\right)$ capacitance values have, for example, been reported for $\mathrm{ZnS}$ ( $\geq 100 \mathrm{~F} \mathrm{~m}^{-2}$; Rönngren et al., 1991) and carbonate minerals
(30-168 F m ${ }^{-2}$; Van Cappellen et al., 1993). Physically, high specific capacitance values indicate a thin and highly structured double layer that is capable of accommodating high charge densities (e.g., Van Cappellen et al., 1993). In contrast, capacitance values for metal (hydr)oxides and silica are typically on the order of $1 \mathrm{~F} \mathrm{~m}^{-2}$.

A limited number of previous studies have described the surface acid-base chemistry of other metal sulfides in terms of surface protonation reactions and surface acidity constants (see Table 3 for a summary). Rönngren et al. (1991) and Sun et al. (1991) constructed comparable models for the surface speciation of zinc and lead sulfides. In their models, the surface is 
Table 2. Model surface protonation reactions and their estimated apparent equilibrium constants derived from the model fit shown in Fig. 5a. The surface speciation based on these data is shown in Fig. 5b.

\begin{tabular}{|c|c|}
\hline Model reactions & $\log K$ \\
\hline $\begin{array}{l}\equiv \mathrm{FeSH}^{0}+\mathrm{H}^{+} \leftrightarrow \equiv \mathrm{FeSH}_{2}^{+} \\
\equiv \mathrm{FeSH}^{0} \leftrightarrow \mathrm{FeS}^{-}+\mathrm{H}^{+} \\
\equiv \mathrm{Fe}_{3} \mathrm{SH}^{0}+\mathrm{H}^{+} \leftrightarrow \equiv \mathrm{Fe}_{3} \mathrm{SH}_{2}^{+} \\
\equiv \mathrm{Fe}_{3} \mathrm{SH}^{0} \leftrightarrow \equiv \mathrm{Fe}_{3} \mathrm{~S}^{-}+\mathrm{H}^{+}\end{array}$ & $\begin{array}{l}\log K_{\text {st1 }}^{\text {app }}=+8.0 \pm 0.1 \\
\log K_{\text {st2 }}^{\text {app }}=-6.5 \pm 0.1 \\
\log K_{\text {akp }}^{\text {app }}=+7.85 \pm 0.05 \\
\log K_{\mathrm{wk} 2}^{\text {app }}<-9.5\end{array}$ \\
\hline
\end{tabular}

described by (i) one type of sulfide site, $\equiv \mathrm{ZnS}$ or $\equiv \mathrm{PbS}$, which can take up one proton; (ii) one type of metal site, $\equiv \mathrm{SZn}$ or $\equiv \mathrm{SPb}$, which can hydroxylate; and (iii) an ion exchange reaction where one cation from the solid is exchanged for two protons. They both found the amount of dissolved divalent metal cations to increase linearly with increasing solid concentration. Combined with an observed ratio of adsorbed protons per released cations close to one and a low total dissolved sulfur concentration, this result led them to conclude that the interaction of protons with the hydrous zinc and lead sulfide surfaces involves the desorption of cations. Our data do not support or refute such an ion exchange reaction. However, since the solubility of disordered mackinawite is far higher than that of the lead and zinc sulfides they studied, it is expected that congruent dissolution is the dominant iron-releasing mechanism.

The value for the surface acidity constant $K_{\mathrm{st2}}^{\mathrm{app}}$ reported here, $10^{-6.5}$, is comparable with the value found by Rönngren et al. (1991) and Sun et al. (1991) for the same surface protonation reaction on zinc $\left(10^{-7.0}\right)$ and lead $\left(10^{-7.1}\right)$ sulfide surfaces (Table 3). The value for $K_{\mathrm{wk} 2}^{\mathrm{app}}$ of $<10^{-9.5}$ reported here could not be constrained more precisely due to the small impact of this value on the fit to the titration curve. In other words, changing the value of $K_{\mathrm{wk} 2}^{\mathrm{app}}$ to even smaller values than $10^{-9.5}$ does not affect the goodness of fit. This indicates that the negatively charged weak surface site is not important at the surface in the $\mathrm{pH}$ range 6 to 8 . Similar values for $K_{\mathrm{wk} 2}^{\mathrm{app}}$ were found by Rönngren et al. (1991) and Sun et al. (1991) for the same surface protonation reaction on zinc $\left(10^{-10.3}\right)$ and lead $\left(10^{-10.1}\right)$ sulfide surfaces (Table 3$)$. The reactions described by $K_{1}^{\text {app }}$ for the strong and the weak sites have not been observed on zinc and lead sulfide surfaces by Rönngren et al. (1991) and Sun et al. (1991).

\subsection{The Physicochemical Nature of the Surface Complexation Model}

The surface charge data derived from acid-base titrations can be fitted by a surface complexation model based on crystal structural considerations. The actual structure of the doubly protonated weak surface site is unclear, however. In Table 2 and reaction (23), it is represented as $\equiv \mathrm{Fe}_{3} \mathrm{SH}_{2}^{+}$. This would mean that the sulfide is coordinated to five atoms, while sulfide in the mackinawite structure has a coordination number $(\mathrm{CN})$ of four. Note that higher coordination numbers of sulfide can be found in, for example, hexagonal pyrrhotite, and troilite $(\mathrm{CN}$ = 6; e.g., Lennie and Vaughan, 1996). An explanation of the apparent fivefold coordination of sulfide in $\equiv \mathrm{Fe}_{3} \mathrm{SH}_{2}^{+}$could be that the second proton is not directly bonded to the sulfur atom but located nearby in the diffuse boundary layer, hence contributing to surface charging. Alternatively, it may be envisioned that one of the $\mathrm{Fe}-\mathrm{S}$ bonds in $\equiv \mathrm{Fe}_{3} \mathrm{SH}_{2}^{+}$is broken to facilitate double protonation of the sulfide. Nevertheless, the asymmetrical surface charge curves (Fig. 2a and b) indicate the presence of at least two types of sites. Using the site densities derived from the crystal structure of $\mathrm{FeS}$, both sites should show double protonation to allow for the observed charge buildup toward lower $\mathrm{pH}$ values.

The surface complexation model proposed here does not take into account surface heterogeneities such as kink and step sites (e.g., Stumm, 1991) or nonstoichiometries, and the physicochemical nature of the actual surface remains unknown. However, the proposed model represents a first description of the surface chemistry of disordered mackinawite. The model is amenable to refinement, especially after existing disagreements on the point of zero charge of metal sulfides have been resolved through combining potentiometric titrations with electrokinetic studies and after spectroscopic analyses have given further insight into the surface site structures and speciation.

Associate editor: D. Vaughan

Table 3. Recommended surface protonation reactions and estimated apparent equilibrium constants from: [1] this study; [2] Rönngren et al., (1991), [3] Sun et al., (1991).

\begin{tabular}{|c|c|c|}
\hline Reaction & $\log K$ & Reference \\
\hline$(\equiv \mathrm{FeS}) \mathrm{H}^{0}+\mathrm{H}^{+} \leftrightarrow(\equiv \mathrm{FeS}) \mathrm{H}_{2}^{+}$ & $+8.0 \pm 0.1$ & [1] \\
\hline$(\equiv \mathrm{FeS}) \mathrm{H}^{0} \leftrightarrow(\equiv \mathrm{FeS})^{-}+\mathrm{H}^{+}$ & $-6.5 \pm 0.1$ & {$[1]$} \\
\hline$\left(\equiv \mathrm{Fe}_{3} \mathrm{~S}\right) \mathrm{H}^{0}+\mathrm{H}^{+} \leftrightarrow\left(\equiv \mathrm{Fe}_{3} \mathrm{~S}\right) \mathrm{H}_{2}^{+}$ & $+7.85 \pm 0.05$ & {$[1]$} \\
\hline$\left(\equiv \mathrm{Fe}_{3} \mathrm{~S}\right) \mathrm{H}^{0} \leftrightarrow\left(\equiv \mathrm{Fe}_{3} \mathrm{~S}\right)^{-}+\mathrm{H}^{+}$ & $<-9.5$ & {$[1]$} \\
\hline \multirow[t]{2}{*}{ 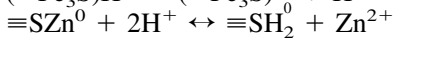 } & $9.59 \pm 0.03$ & for synthetic $\mathrm{ZnS}$, [2] \\
\hline & $9.65 \pm 0.03$ & for sphalerite, [2] \\
\hline \multirow[t]{2}{*}{$\equiv \mathrm{SZn}^{0}+\mathrm{H}_{2} \mathrm{O} \leftrightarrow \equiv \mathrm{SZnOH}^{-}+\mathrm{H}^{+}$} & $-10.28 \pm 0.10$ & for synthetic $\mathrm{ZnS}$, [2] \\
\hline & $-10.29 \pm 0.10$ & for sphalerite, [2] \\
\hline \multirow[t]{2}{*}{$\equiv \mathrm{ZnS}^{0}+\mathrm{H}^{+} \leftrightarrow \equiv \mathrm{ZnSH}^{+}$} & $6.91 \pm 0.03$ & for synthetic $\mathrm{ZnS}$, [2] \\
\hline & $7.14 \pm 0.03$ & for sphalerite, [2] \\
\hline \multirow[t]{2}{*}{$\equiv \mathrm{SPb}^{0}+2 \mathrm{H}^{+} \leftrightarrow \equiv \mathrm{SH}_{2}^{0}+\mathrm{Pb}^{2+}$} & $9.48 \pm 0.027$ & for synthetic $\mathrm{PbS},[3]$ \\
\hline & $10.21 \pm 0.024$ & for galena, [3] \\
\hline \multirow[t]{2}{*}{$\equiv \mathrm{SPb}^{0}+\mathrm{H}_{2} \mathrm{O} \leftrightarrow \equiv \mathrm{SPbOH}^{-}+\mathrm{H}^{+}$} & $-10.0 \pm 0.09$ & for synthetic $\mathrm{PbS},[3]$ \\
\hline & $-10.2 \pm 0.09$ & for galena, [3] \\
\hline \multirow[t]{2}{*}{$\equiv \mathrm{PbS}^{0}+\mathrm{H}^{+} \leftrightarrow \equiv \mathrm{PbSH}^{+}$} & $7.11 \pm 0.044$ & for synthetic $\mathrm{PbS},[3]$ \\
\hline & $7.15 \pm 0.047$ & for galena, [3] \\
\hline
\end{tabular}


Acknowledgments - We thank Lorenzo Spadini (Grenoble University) for generously sharing data and contributing to the surface structural model discussion. Philippe Van Cappellen and Thilo Behrends (Utrecht University) are also gratefully acknowledged for insightful discussions over the course of this study. We also thank three anonymous reviewers and the associate editor Professor D. Vaughan for their comments, which helped to improve the manuscript. This research was financially supported by the Netherlands Organization of Scientific Research (NWO/ALW grant 750.197.06 to M. W.), by the Donder's Chair Fellowship (Utrecht University) to L. C., and by NERC grant NRE/L/ S/2000/00611 to D. R. This research was conducted under the program of the Netherlands Research School of Sedimentary Geology.

\section{REFERENCES}

Arakaki T. and Morse J. W. (1993) Coprecipitation and adsorption of $\mathrm{Mn}$ (II) with mackinawite (FeS) under conditions similar to those found in anoxic sediments. Geochim. Cosmochim. Acta 57, 9-14.

Bayens B. and Bradbury M. H. (1997) A mechanistic description of Ni and $\mathrm{Zn}$ sorption on Na-montmorillonite Part I: Titration and sorption measurements. J. Contam. Hydr. 27, 199-222.

Bebié J., Schoonen M. A. A., Fuhrman M., and Strongin D. R. (1998) Surface charge development on transition metal sulfides: An electrokinetic study. Geochim. Cosmochim. Acta 62, 633-642.

Benning L., Wilkin R. T., and Barnes H. L. (2000) Reaction pathways in the Fe-S system below $100^{\circ} \mathrm{C}$. Chem. Geol. 167, 25-51.

Berner R. A. (1967) Diagenesis of iron sulfide in recent marine sediments. In Estuaries (ed. G. H. Lauff,), pp. 268-272, American Association for the Advancement of Science.

Charlet L., Wersin P., and Stumm W. (1990) Surface charge of $\mathrm{MnCO}_{3}$ and $\mathrm{FeCO}_{3}$. Geochim. Cosmochim. Acta 54, 2329-2336.

Davison W. (1991) The solubility of iron sulfides in synthetic and natural waters at ambient temperature. Aquat. Sci. 53, 309-329.

Davison W., Philips N., and Tabner B. J. (1999) Soluble iron sulfide species in natural waters: reappraisal of their stoichiometry and stability constants. Aquat. Sci. 61, 23-43.

Dekkers M. J. and Schoonen M. A. A. (1994) An electrokinetic study of synthetic greigite and pyrrhotite. Geochim. Cosmochim. Acta 58, 4147-4153.

Dzombak D. A. and Morel F. M. M. (1990) Surface Complexation Modelling, Hydrous Ferric Oxide. Wiley \& Sons.

Foissy A. and Persello J. (1998) Surface group ionization on silicas. In The Surface Properties of Silicas (ed. A. P. Legrand), pp. 365-414, Wiley \& Sons.

Gabriel U., Charlet L., Schlapfer C. W., Vial J. C., Brachmann A., and Geipel G. (2001) Uranyl surface speciation on silica particles studied by time-resolved laser-induced fluorescence spectroscopy. J. Coll. Interf. Sci. 239, 358-368.

Herbert R. B. Jr., Benner S. G., Pratt A. R., and Blowes D. W. (1998) Surface chemistry and morphology of poorly crystalline iron sulfides precipitated in media containing sulfate-reducing bacteria. Chem. Geol. 144, 87-97.

Hiemstra T., Venema P., and Van Riemsdijk W. H. (1996) Intrinsic proton affinity of reactive surface groups of metal (hydr)oxides: the bond valence principle. J. Coll. Interface Sci. 184, 680-692.

Kornicker W. A. (1988) Interactions of Divalent Cations with Pyrite and Mackinawite in Seawater and Sodium-Chloride Solutions. Ph.D. Thesis, Texas A\&M University.

Kuo S. and McNeal B. L. (1984) Effects of pH and Phosphate on cadmium sorption by a hydrous ferric oxide. Soil Sci. Soc. Am. J. 48, $1040-1044$.

Lennie A. R. and Vaughan D. J. (1996) Spectroscopic studies of iron sulfide formation and phase relations at low temperatures. Min. Spectr. 5, 117-131.

Luther G. W. III (1991) Pyrite synthesis via polysulfide compounds. Geochim. Cosmochim. Acta 55, 2839-2849.

Luther G. W. and Ferdelman T. G. (1993) Voltammetric characterization of iron(II) sulfide complexes in laboratory solutions and in marine waters and porewaters. Envir. Sci. Technol. 27, 1154-1163.
Luther G. W. III, Rickard D., Theberge S., and Olroyd A. (1996) Determination of metal (bi)sulfide stability constants of $\mathrm{Mn}^{2+}$, $\mathrm{Fe}^{2+}, \mathrm{Co}^{2+}, \mathrm{Ni}^{2+}, \mathrm{Cu}^{2+}$ and $\mathrm{Zn}^{2+}$ by voltammetric methods. Envir. Sci. Technol. 30, 671-679.

Milonjić S. K. (1987) Determination of surface ionization and complexation constants at colloidal silica/electrolyte interface. Colloids Surf. 23, 301-312.

Morel F. M. M. and Hering J. G. (1993) Principles and Applications of Aquatic Chemistry. Wiley and Sons.

Morse J. W. and Arakaki T. (1993) Adsorption and coprecipitation of divalent metals with mackinawite (FeS). Geochim. Cosmochim. Acta 57, 3635-3640.

Morse J. W. and Luther G. W. III (1999) Chemical influences on trace metal-sulfide interactions in anoxic sediments. Geochim. Cosmochim. Acta 63, 3373-3378.

Morse J. W., Millero F. J., Cornwell J. C., and Rickard D. (1987) The chemistry of the hydrogen sulfide and iron sulfide systems in natural waters. Earth Sci. Rev. 24, 1-42.

Park S. W. and Huang C. P. (1987) The surface acidity of hydrous CdS J. Colloid and Interface Sci. 117, 431-441.

Pauling L. (1939) The Nature of the Chemical Bond 1st Edition Cornell University Press.

Pauling L. (1960) The Nature of the Chemical Bond 3rd Edition Cornell University Press.

Pauling L. (1970) Crystallography and chemical bonding of sulfide minerals. Min. Soc. Am. Spec. Pap. 3, 125-131.

Prasad B. (1976) Charge Characteristics and Phosphate Adsorption on Ferruginous Soils and Synthetic Iron Oxides. Ph.D. Thesis, University of Minnesota.

Renders P. J. and Seward T. M. (1989) The adsorption of thio gold(I) complexes by amorphous $\mathrm{As}_{2} \mathrm{~S}_{3}$ and $\mathrm{Sb}_{2} \mathrm{~S}_{3}$ at 25 and $90^{\circ} \mathrm{C}$. Geochim. Cosmochim. Acta 53, 255-267.

Rickard D. (1989) Experimental concentration-time curves for the iron(II) sulfide precipitation process in aqueous solutions and their interpretation. Chem. Geol. 78, 315-324.

Rickard D. (1995) Kinetics of FeS precipitation: Part 1. Competing reaction mechanismsGeochim. Cosmochim. Acta 59, 4367-4379.

Rickard D. and Luther G. W. III (1997) Kinetics of pyrite formation by the $\mathrm{H}_{2} \mathrm{~S}$ oxidation of iron (II) monosulfide in aqueous solutions between 25 and $125^{\circ} \mathrm{C}$ : The mechanism. Geochim. Cosmochim. Acta 61, 135-147.

Rönngren L., Sjöberg S., Sun Z., Forsling W., and Schindler P. W. (1991) Ion exchange and acid/base reactions at the $\mathrm{ZnS}-\mathrm{H}_{2} \mathrm{O}$ interface. J. Colloid and Interface Sci. 145, 396-404.

Schulthess C. P. and Sparks D. L. (1986) Backtitration technique for proton isotherm modeling of oxide surfaces. Soil Sci. Soc. Am. J. 50, $1406-1411$.

Spadini L., Bott M., Wehrli B., and Manceau A. (2003) Analysis of the major $\mathrm{Fe}$ bearing phases in recent lake sediments by EXAFS spectroscopy. Aquat. Geochem. 9, 1-17.

Sposito G. (1984) The Surface Chemistry of Soils. Oxford University Press.

Strazhesko D. N., Strelko V. B., Belyakov V. N., and Rubanik S. C. (1974) Mechanism of cation exchange on silica gels. J. Chromatogr. 102, 191-195.

Stumm W. (1991) Chemistry of the Solid-Water Interface, Processes at The Mineral-Water and Particle-Water Interface in Natural Systems. Wiley \& Sons.

Stumm W. and Morgan J. J. (1981) Aquatic Chemistry. Wiley-Interscience.

Suleimonov O. M. and Seward T. M. (1997) A spectrophotometric study of hydrogen sulfide ionisation in aqueous solutions to $350^{\circ} \mathrm{C}$. Geochim. Cosmochim. Acta 61, 5187-5198.

Sun Z. X., Forsling W., Rönngren L., Sjöberg S., and Schindler P. W. (1991) Surface reactions in aqueous metal sulfide systems. 3. Ion exchange and acid/base properties of hydrous lead sulfideColloids and Surf. 59, 243-254.

Taylor L. A. and Finger L. W. (1970) Structural refinement and composition of mackinawite. Carnegie Inst. Washington Geophys. Lab. Ann. Rep. 69, 318-322.

Van Cappellen P., Charlet L., Stumm W., and Wersin P. (1993) A surface complexation model of the carbonate mineral-aqueous solution interface. Geochim. Cosmochim. Acta 57, 35053518. 
Viollier E., Inglett P. W., Hunter K., Roychoudhury A. N., and Van Cappellen P. (2000) The ferrozine method revisited: Fe(II)$\mathrm{Fe}(\mathrm{III})$ determination in natural waters. Appl. Geochem. 15, 785-790.

Watson J. H. P., Cressey B. A., Roberts A. P., Ellwood D. C., Charnock J. M., and Soper A. K. (2000) Structural and magnetic studies on heavy-metal-adsorbing iron sulphide nanoparticles produced by sulphate-reducing bacteria. J. of Magn. and Magn. Materials 214, 13-30. Wharton M. J., Atkins B., Charnock J. M., Livens F. R., Pattrick R. A. D., and Collison D. (2000) An X-ray absorption spectroscopy study of the coprecipitation of Tc and Re with mackinawite (FeS). Appl. Geochem. 15, 347-354.

Widler A. M. and Seward T. M. (2002) The adsorption of $\operatorname{gold}(\mathrm{I})$ hydrosulphide complexes by iron sulfide surfaces. Geochim. Cosmochim. Acta 66, 383-402.

Wolthers M., van der Gaast S. J., and Rickard D. (2003) The structure of disordered mackinawite. Am. Mineral. 88, 2007-2015.

Zhang J.-Z and Millero F. J. (1994) Investigation of metal sulfide complexes in sea water using cathodic stripping square wave voltammetry. Analyt. Chim. Acta 284, 497-504. 